\title{
Transposable elements from the mesophragmatica group of Drosophila
}

\author{
Erika Germanos ${ }^{1}$, Nina R. Mota ${ }^{2}$ and Elgion L.S. Loreto ${ }^{1,2}$ \\ ${ }^{1}$ Pograma de Pós-Graduação em Biodiversidade Animal, Centro de Ciências Naturais e Exatas, \\ Universidade Federal de Santa Maria, RS, Brazil. \\ ${ }^{2}$ Departamento de Biologia, Centro de Ciências Naturais e Exatas, Universidade Federal de Santa Maria, \\ Santa Maria, RS, Brazil.
}

\begin{abstract}
Transposable elements (TEs) are middle repetitive DNA sequences classified into families according to their sequence similarities, such elements can playing an important role in the evolutionary process of their host genomes. There are many reports on the distribution of TEs in the fruit fly genus Drosophila, although there is relatively little information relating to the Neotropical mesophragmatica group of Drosophila, probably the most typical cluster of species occurring almost exclusively in the Andes mountains. Dot Blot and PCR analyses was used to study the distribution of some TEs (I, mariner, hobo, gypsy, Tom/17.6, micropia and P elements) within the mesophragmatica group of Drosophila. We found gypsy elements in all the mesophragmatica group species studied and mariner elements were absent only from Drosophila pavani but $P$ element homologous sequences were present only in $D$. pavaniand Drosophila gasiciand the other TEs (I, hobo, Tom/17.6, micropia) were not found in any of the species investigated.
\end{abstract}

Key words: Drosophila, mesophragmatica, phylogenetic distribution, transposable elements.

Received: September 14, 2005; Accepted: April 10, 2006.

Transposable elements (TEs) are a theme of much interest because they form a significant portion of genomes and can play an important role in the evolutionary process of their host genomes (Kidwell and Lisch, 2000).

Two major classes are distinguished by their different modes of transposition (Finnegan, 1992). Class I elements use reverse transcriptase to transpose by means of an RNA intermediate and are called retroelements. They include long terminal repeat (LTR) retrotransposons as well as long and short interspersed elements (LINES and SINES, respectively). Long terminal repeat retrotransposons are closely related to other retroelements of major interest, such as retroviruses. Class II elements transpose directly from DNA to DNA and include transposons such as the $P$ and hobo elements in Drosophila. Recently, two novel groups of DNA transposons have been described. One, called helitrons, transpose by some form of 'rolling circle' replication mechanism. The other, miniature inverted-repeats transposable elements (MITEs), are very short elements which are not autonomous and normally present an elevated copy number (Poulter et al., 2003).

Send correspondence to Elgion L.S. Loreto. Departamento de Biologia, Centro de Ciências Naturais e Exatas, Universidade Federal de Santa Maria, prédio 16-A, 97105.00 Santa Maria, RS, Brazil. E-mail: elgion@base.ufsm.br.
During their "life-cycle" in the host genomes TEs seem to experience a complex evolutionary pattern and may suffer: $i$ ) horizontal transfer, ii) stochastic loss, iii) inactivation and subsequent sequence degeneration and, sometimes, $i v$ ) revival by sequence recombination. Furthermore, ancestral polymorphism with different evolutionary rates of variable copies can make it more difficult to analyze the complex pattern of TE evolution (Herédia et al., 2004; Brookfield, 2005).

The fruit fly genus Drosophila and related species are especially useful for investigating the role of transposable elements in evolution, with 96 different TEs families having so far been found in the sequenced Drosophila melanogaster genome (Kaminker et al., 2002). Furthermore, sequencing of the Drosophila pseudoobscura genome has also been finished and ten other Drosophila genomes are in final process of sequencing (http://rana. lbl.gov/drosophila/), which will help to further clarify the evolutionary role played by the TEs. However, to understand the origin of transposable elements and how they are lost or gained by species and the role they play in genome evolution there is a need for a wide-ranging screening program of those TEs already identified in the Drosophila genomes already sequenced. Some extensive analyses have been made for a number of different Drosophila TEs (see 
the review by Biémont and Cizeron, 1999), such as the $P$ element family (Stacey et al., 1986; Anxolabéhère and Periquet, 1987; Daniels et al., 1990a; Loreto et al., 1998); I (Bucheton et al., 1986; Stacey et al., 1986); gypsy (Stacey et al., 1986; Heredia et al., 2004); hobo (Daniels et al., 1990b, Loreto et al., 1998); micropia (Almeida et al. 2001; 2003); and mariner (Maruyama and Hartl, 1991; Brunet et al., 1994).

Although considerable data about the distribution of TEs in Drosophila are emerging on the evolution of these sequences in the Drosophila, few data are available on the Neotropical mesophragmatica group of Drosophila which are probably the most typical cluster of species occurring almost exclusively in the Andes Mountains (Brncic et al., 1971). In this group, Drosophila pavani has been investigated for TEs and sequences homologous to gypsy and copia (Stacey et al., 1986) and Bari1 (Moschetti et al., 1998) have been found but not $P$ and $I$ homologous sequences (Brookfield et al., 1984; Bucheton et al., 1986). Furthermore, gypsy sequences, but not $P$ and hobo sequences, have been found in Drosophila gaucha (Loreto et al., 1998).

This paper provides a brief description of the distribution of I, mariner, hobo, gypsy, Tom/17.6, micropia and $P$ element TEs in the mesophragmatica group of Drosophila.

The species of the mesophragmatica group of Drosophila studied were: D. pavani (Brncic, 1957); D. viracochi (Brncic and Koref-Santibanez, 1957); D. brncici (Hunter and Hunter, 1964) and D. gasici (Brncic, 1957). For D. gasici three populations (Arica-Chile, Colombia, Cochabamba-Bolivia) were analyzed. All strains employed were maintained in the laboratory by massal mating under standard conditions. Genomic DNA was prepared from approximately 100 adult flies per sample and extracted according to Jowett (1986) with minor modifications.

Polymerase chain reactions (PCR) were performed in $25 \mu \mathrm{L}$ volumes using approximately $25 \mathrm{ng}$ of template DNA, $20 \mathrm{pMol}$ of each primer, $0.2 \mathrm{mM}$ of each dNTP, 1.5 to $2.5 \mathrm{mM} \mathrm{MgCl}_{2}$ and 1 unit of Taq DNA polymerase
(Invitrogen) in 1x Polymerase Buffer. The PCR conditions, the used primers and also the expected fragment sizes are presented in the Table 1. For Tom/17.6 elements the degenerated primers were designed using the alignment of Tom element from $D$. ananassae and 17.6 and 297 from $D$. melanogaster described by Tanda et al. (1988).

For $P$ and mariner elements, after PCR the product was separated on $0.8 \%(\mathrm{w} / \mathrm{v})$ agarose gel, blotted onto a Hybond $\mathrm{N}+$ nylon membrane (Amersham Biosciences) and hybridized with the $P$ and mariner probes to confirm the specificity of amplification.

The transposable elements $I$, mariner and micropia were investigated by Dot Blot for all species. For each strain about $2 \mu \mathrm{g}$ of DNA was boiled for $5 \mathrm{~min}$, cooled for 5 min in a freezer, applied to a Hybond $\mathrm{N}+$ nylon membrane and fixed at $80^{\circ} \mathrm{C}$ for $2 \mathrm{~h}$ before being hybridized to a random primer-labeled probe at $60^{\circ} \mathrm{C}$ in $5 \mathrm{x} \mathrm{SSC}$ containing $0.1 \%(\mathrm{v} / \mathrm{v})$ SDS; $5 \%(\mathrm{w} / \mathrm{v})$ dextran sulfate and a 20 -fold dilution of liquid block. The filters were washed twice with SSC $0.2 \mathrm{X}$ and $0.5 \% \operatorname{SDS}(\mathrm{w} / \mathrm{v})$ for $15 \mathrm{~min}$ at $60^{\circ} \mathrm{C}$. Hybridization and detection were performed using Gene Images KIT (Amersham Biosciences) according to the manufacture's instructions.

The following probes were used in Dot and Southern Blot experiments: the Mos1 plasmid for mariner (Maruyama and Hartl, 1991); the pI786 plasmid containing a $1 \mathrm{~kb}$ insert derived from the internal region of the $D$. melanogaster I element (see Fawcett et al., 1986); the amplified PCR fragment from the micropia $\mathrm{dhMiF} 2$ plasmid (Huisjer et al., 1988); the PCR fragment from the gypsy pGGHS plasmid (Dorsett et al., 1989); the amplified PCR fragment from the $P$ element $\mathrm{p} \pi 25.1$ plasmid (O'Hare and Rubin, 1983); and the amplified PCR fragment from the Tom element pTOM plasmid (Tanda et al., 1988). The primers used to amplify the probes are presented in Table 1.

The status of the species of the mesophragmatica group related to the presence of the I, hobo, Tom/17.6, mariner, micropia, $P$ and gypsy transposable elements is presented in Table 2.

Table 1 - The PCR conditions, primers and expected size of PCR products.

\begin{tabular}{|c|c|c|c|c|}
\hline Element & Primers & PCR conditions & Expected size & Reference \\
\hline Tom $/ 17.6$ & $\begin{array}{l}\text { T12A (5' AGTWTGGGCSACAAARAC 3') } \\
\text { T12B (5'CCGTCYCTRTCYGCCTTT 3') }\end{array}$ & $\begin{array}{l}95^{\circ} \mathrm{C} \text { for } 1 \mathrm{~min} ; 55^{\circ} \mathrm{C} \text { for } 45 \mathrm{~s} \\
72^{\circ} \mathrm{C} \text { for } 1 \mathrm{~min}(35 \text { cycles })\end{array}$ & $\pm 1 \mathrm{~kb}$ & \\
\hline gypsy & $\begin{array}{l}\text { GYP3S2 (5' AAAGGCGAYTTGGTTGACACTCC 3') } \\
\text { GYP3AS2 (5'CARGTGGCTRGGTTGRGTGTG 3') }\end{array}$ & $\begin{array}{l}96^{\circ} \mathrm{C} \text { for } 15 \mathrm{~s} ; 55^{\circ} \mathrm{C} \text { for } 30 \mathrm{~s} \\
72^{\circ} \mathrm{C} \text { for } 1 \mathrm{~min} 30 \mathrm{~s}(35 \text { cycles })\end{array}$ & $485 \mathrm{bp}$ & $\begin{array}{l}\text { Herédia et al. } \\
\quad(2004)\end{array}$ \\
\hline hobo & $\begin{array}{l}\text { P651 (5' CACCTCCAATTTATCCCGCC 3') } \\
\text { P1597 (5' GGATGGAATACGAAGC 3') }\end{array}$ & $\begin{array}{l}94^{\circ} \mathrm{C} \text { for } 1 \mathrm{~min} ; 50{ }^{\circ} \mathrm{C} \text { for } 45 \mathrm{~s} \\
72^{\circ} \mathrm{C} \text { for } 1 \mathrm{~min}(35 \text { cycles })\end{array}$ & 946 bp. & Klein (2002) \\
\hline micropia & $\begin{array}{l}\text { MIC1777 (5' CTCCCCTTTTGCCAGTCCT 3') } \\
\text { MIC2570 (5' TTGAGCTAGCGT CGGTGTG 3') }\end{array}$ & $\begin{array}{l}95^{\circ} \mathrm{C} \text { for } 1 \mathrm{~min} ; 55^{\circ} \mathrm{C} \text { for } 45 \mathrm{~s} \\
72^{\circ} \mathrm{C} \text { for } 1 \mathrm{~min}(35 \text { cycles })\end{array}$ & $812 \mathrm{bp}$ & $\begin{array}{l}\text { Lankenau et al. } \\
\quad \text { (1994) }\end{array}$ \\
\hline mariner & $\begin{array}{l}\text { Mar-fw (5', TGGGTNCCNCAYGARYT 3') } \\
\text { Mar-rv (5' GGNGCNARRTCNGGNSWRTA 3') }\end{array}$ & $\begin{array}{l}95^{\circ} \mathrm{C} \text { for } 1 \mathrm{~min} ; 53{ }^{\circ} \mathrm{C} \text { for } 45 \mathrm{~s} \\
72^{\circ} \mathrm{C} \text { for } 1 \mathrm{~min}(35 \text { cycles })\end{array}$ & $473 b p$ & $\begin{array}{r}\text { Robertson and } \\
\text { Macleod (1993) }\end{array}$ \\
\hline$P$ & $\begin{array}{l}2684 \text { (5', GCTATTTGNYTNCAYACCGCNGG 3') } \\
2687 \text { (5' CCCAATGNATWGCANCGTCTKAT 3') }\end{array}$ & $\begin{array}{l}94{ }^{\circ} \mathrm{C} \text { for } 45 \mathrm{~s} ; 50^{\circ} \mathrm{C} \text { for } 45 \mathrm{~s} \\
72{ }^{\circ} \mathrm{C} \text { for } 1 \min (35 \text { cycles })\end{array}$ & $\pm 1 \mathrm{~kb}$ & $\begin{array}{l}\text { Lee } \text { et al. } \\
\text { (1999) }\end{array}$ \\
\hline
\end{tabular}


Table 2 - Distribution of transposable elements in mesophragmatica species group.

\begin{tabular}{|c|c|c|c|c|c|c|c|c|c|c|c|c|c|}
\hline \multirow[b]{3}{*}{ Drosophila species } & \multicolumn{13}{|c|}{ Transposable element presence $(+)$ or absence (-) } \\
\hline & \multicolumn{2}{|c|}{ gypsy } & \multicolumn{2}{|c|}{$P$} & \multicolumn{2}{|c|}{ hobo } & \multicolumn{2}{|c|}{ 17.6/tom } & \multicolumn{2}{|c|}{ mariner } & \multicolumn{2}{|c|}{ micropia } & \multirow{2}{*}{$\begin{array}{c}I \\
\text { Dot }\end{array}$} \\
\hline & Dot & PCR & Dot & PCR & Dot & PCR & Dot & PCR & Dot & PCR & Dot & PCR & \\
\hline D. gasici (Arica) & + & + & - & - & - & - & - & - & - & + & - & - & - \\
\hline D.gasici(Colombia) & + & + & - & + & - & - & - & - & - & + & - & - & - \\
\hline D.gasici (Cocha) & + & + & - & - & - & - & - & - & - & + & - & - & - \\
\hline D.brncici & + & + & - & - & - & - & - & - & - & + & - & - & - \\
\hline D.pavani & + & + & - & - & - & - & - & - & - & - & - & - & - \\
\hline D.viracochi & + & + & - & + & - & - & - & - & - & + & - & - & - \\
\hline
\end{tabular}

The gypsy homologous sequences were present in all the species tested. The ENV fragment amplified by PCR corresponded to the expected size $(0.5 \mathrm{~kb})$ and a strong band was produced (Figure 1). Homology with the gypsy sequence was confirmed by Dot Blot of the PCR products and also with the genomic DNA probed with the $D$. melanogaster gypsy sequence. The presence of the gypsy sequence in all mesophragmatica group species tested was expected because all Drosophila species so far investigated have gypsy homologous sequences (Stacey et al., 1986, Herédia et al., 2004). Some reports have suggested that the wide gypsy distribution in Drosophila could be related to the fact that gypsy is a retrovirus and therefore could have a high capacity to invade different genomes (Kim et al., 1994; Prud'homme et al., 1994; Heredia et al., 2004). However, to test whether the occurrence of gypsy in the genome of mesophragmatica group species is related to its presence in the ancestral genome or is a product of recent invasion, the gypsy related sequences from these species need to be cloned and sequenced.

Using degenerated primers we were able to amplify $P$ homologous sequences in D. pavani and in the Colombia population of D. gasici, while the two other populations of this species analyzed were negative. The other species tested also lacked $P$ sequences (Figure 1). The PCR product obtained with the mesophragmatica group species were of the expected size but the band was weak. In order to confirm the homology with the $P$ element, the PCR products were transferred to a nylon membrane and hybridized to the D. melanogaster $P$ element.

The $P$ element family is one of the best investigated eukaryote TEs, with the first studies having indicated that $P$-homologous sequences are basically confined to the subgenus Sophophora (Daniels et al., 1990a) and that their presence in $D$. melanogaster occurs by horizontal transfer from D. willistoni (Kidwell, 1992). Later analysis, however, has shown a wider distribution of $P$ homologous sequences, which have now also been described in other dipterans such as the blow fly (Lucilia cuprina; Perkins and Howells, 1992), the house fly (Musca domestica; Lee et al., 1999) and the mosquito (Anopheles gambiae; Sarkar et al.,
2003, Oliveira de Carvalho et al., 2004) as well as in vertebrates such as the zebrafish, chicken, pig, cow and humans (Quesneville et al., 2005, Hammer et al., 2005). At the moment, the dominant hypothesis sustains that the $P$ element is an old component of animal genomes maintained by vertical transfer but which could also suffer horizontal transfer and domestication to new functions (Hammer et al., 2005).

In our laboratory we have obtained some very divergent $P$ sequences from the tripunctata and cardini groups of Drosophila (unpublished results). The differences observed in intensity of hybridization signal in the Southern Blots of $P$ element PCR products obtained from mesophragmatica group species and the control $P$ element from $D$. melanogaster suggest that there is little similarity between the $P$ sequences from mesophragmatica group species and the $D$. melanogaster $P$ element. Cloning and sequencing these sequences could contribute to elucidating the origin of the $P$ element family.

The hobo element was initially described as present only in the genomes of some melanogaster group species (Daniels et al., 1990b, Periquet et al., 1994). However, hobo sequences have also been described in some $D$. willistoni strains which show a weak hybridization signal with the $D$. melanogaster hobo probe (Loreto et al.,1998). Klein (2002) sequencing part of this $D$. willistoni element showing it is hobo divergent sequence. Out of Drosophila genus, hobo-like elements have been found in some species of Diptera, like Musca domestica (Atkinson et al., 1993) and different tephritids (Handler and Gomez, 1996; Torti et al., 2005) and, also in some species of Lepidoptera (Borsatti et al., 2003). However, using the primers described by Klein (2002) we have not obtained success in amplifying hobo related sequences in the mesophragmatica group.

Using the degenerated primers we were able to amplify sequences of the retrotransposons from the Tom/17.6 families in different Drosophila species but no amplification occurred when DNAs of mesophragmatica species were used in the PCR assay, which could either mean that these retrotransposon families are not present in the mesophragmatica genome or the sequences are divergent in the primer region. 
Using the Drosophila mauritiana (MOS1) as probe to mariner, no homologous sequences were observed in the species studied. However, Brunet et al., (1994) used degenerated primers to amplify mariner homologous sequences in some Drosophila species which were first thought not to
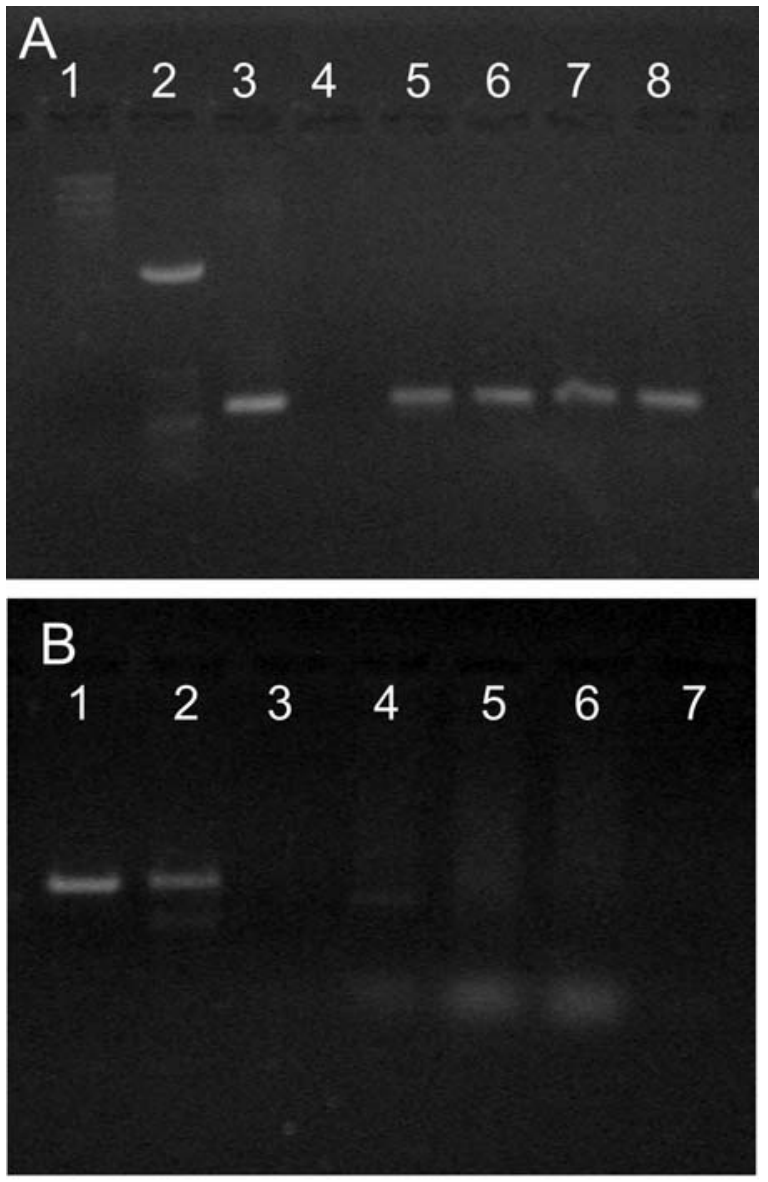

4.

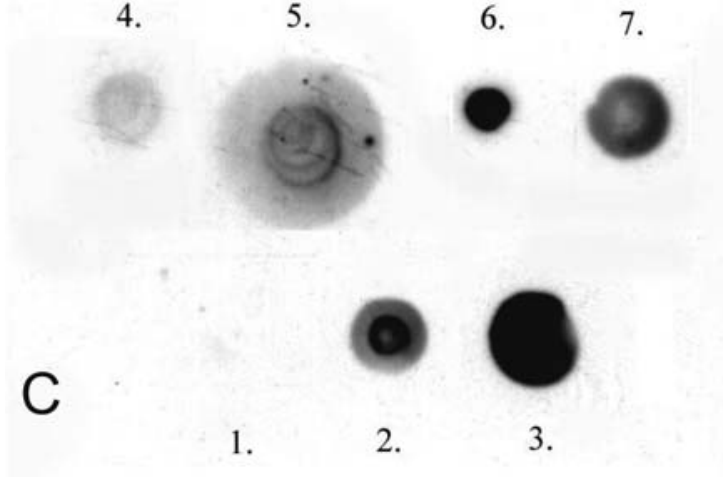

Figure 1 - A) PCR amplification of gypsy element: $1=\lambda$ Hind III fragments; $2=1 \mathrm{~kb}$ Invitrogen DNA Ladder; $3=$ positive control (pGGHS plasmid); $4=$ negative control $(5-D$. gasici $) ; 6=D$. brncici $7=D$. pavani; $8=$ D. viracochi. B) PCR amplification of $P$ element: $1=$ pp 25.1 plasmid; $2=D$. gasici $($ Colombia $) ; 3=D$. gasici $($ Arica $) ; 4=D$. viracochi $; 5=D$. brncici; $6=D$. pavani $; 7=$ negative control. C) Dot blot of genomic DNA from mesophragmatica species probed with gypsy element: $1=$ negative control (pUC 18 plasmid); 2 = positive control (pGGHS plasmid); $3=D$. pavani $; 4=$ D. gasici (Colombia); $5=$ D. gasici $($ Arica); $6=$ D. brncici; $7=D$. viracochi contain mariner sequences because such sequences had not been detected by the Southern Blot technique. Our results using the degenerated primers described by Robertson and Macleod (1993) have shown that the mariner TE is present in D. brncici, D. viracochi and D. gasici, with the latter species showing an amplification fragment about $300 \mathrm{bp}$ smaller than that displayed by the other species. However, D. pavani showed no signs of having the mariner sequence in its genome either by PCR or Dot Blot assay.

The micropia TE is a representative of a family of transposable elements discovered as constituents of the Y-chromosomal fertility genes of Drosophila hydei (Huijser, et al., 1998). Several members of the micropia family have been recovered from $D$. melanogaster and, recently, from saltans (Almeida et al., 2001) and repleta (Almeida et $a l ., 2003)$ group species. However, using degenerated primers to micropia we obtained no amplification using mesophragmatica species DNA as the PCR template. Also, the Dot Blot was negative for the presence of micropia homologous sequences in the genomic DNA from all the species tested.

The I element was also absent from the mesophragmatica genome as indicated by Dot Blot experiments. This retrotransposon element has its distribution restricted to the melanogaster group, which has been reported by other authors (Bucheton et al., 1986, Stacey et al., 1986, Loreto et al., 1998).

Studies on the presence and distribution of TEs in the genus Drosophila have shown discrepancies between phylogenetics trees of TEs and their host. Some intriguing horizontal transfer cases have initially been indicated by wide screening analyses of TE distribution (Daniels et al., 1990a; Loreto et al., 1998, Herédia et al., 2004, Almeida and Carareto, 2005). Studies on the phylogenetic distribution of TEs lead to a better understanding of the evolution of such elements and their influence on the host genome. This paper provides some information on the distribution of TEs in mesophragmatica group species and poses questions which may stimulate further research on the evolution of gypsy, mariner and $P$ element in this group.

\section{Acknowledgments}

This work was supported by grants from the Brazilian agencies FAPERGS (grant number 01/0927.4) and FIPEUFSM and fellowships from CAPES (EG) and CNPq (ELSL and NRM). We are grateful to Dr. Luciano Basso da Silva and Dr. Marlise Santos and two anonymous referees for suggestions and to Juliana Santos for reviewing the English.

\section{References}

Almeida LM and Carareto CM (2005) Multiple events of horizontal transfer of the Minos transposable element between Drosophila species. Mol Phylogenet Evol 35:583-94. 
Almeida LM, Castro JP and Carareto CM (2001) Micropia transposable element occurence in Drosophila species of the saltans group. Dros Inf Serv 84:114-117.

Almeida LM, Castro JP and Carareto CM (2003) Identification of two subfamilies of micropia transposable element in species of the repleta group of Drosophila. Genetica 167:1-10.

Anxolabéhère D and Periquet G (1987) $P$-homologous sequences in Diptera are not restricted to the Drosophilidae family. Genet Iber 39:211-222.

Atkinson PW, Warren WD and O'Brochta DA (1993) The hobo transposable element of Drosophila can be cross-mobilized in houseflies and excises the $A c$ element of maize. Proc Natl Acad Sci USA 90:9693-9697.

Biémont C and Cizeron G (1999) Distribution of transposable elements in Drosophila species. Genetica 105:43-62.

Borsatti F, Azzoni P and Mandrioli M (2003) Identification of a new hobo element in the cabbage moth, Mamestra brassicae (Lepidoptera). Hereditas 139:151-155.

Brncic D (1957) A comparative study of chromosomal variation in species of the mesophragmatica group of Drosophila. Genetics 42:789-805.

Brncic D and Koref-Sebastiañez S (1957) The mesophragmatica species group of Drosophila. Evolution 11:300-310.

Brncic D, Puliyampetta SN and Marshall RW (1971) Cytotaxonomic relationships within mesophragmatica species group of Drosophila. Studies in Genetics VI. Univ Texas Publ 7103:1-16.

Brookfield JFY (2005) The ecology of the genome - Mobile DNA elements and their hosts. Nature Rev Genet 6:128-134.

Brookfield JFY, Montgomery E and Langley CH (1984) Apparent absence of transposable elements related to the $P$ element of D. melanogaster in other species of Drosophila. Nature 310:330-332.

Brunet F, Godin F, David JR and Capy P (1994) The mariner transposable element in the Drosophilidae family. Heredity 73:377-385.

Bucheton AM, Simonelig C, Vaury C and Crozatier M (1986) Sequences similar to the $I$ transposable element involved in I-R hybrid dysgenesis in Drosophila melanogaster occur in other Drosophila species. Nature 322:650-652.

Daniels SB, Peterson KR, Strausbaugh LD, Kidwell MG and Chovnick A (1990a) Evidence for horizontal transmission of the $P$ transposable element between Drosophila species. Genetics 124:339-355.

Daniels SB, Chovnick A and Boussy IA (1990b) Distribution of hobo transposable elements in the genus Drosophila. Mol Biol Evol 7:589-606.

Dorsett D, Viglianti GA, Rutledge BJ and Meselson M (1989) Alteration of $h s p 82$ gene expression by the gypsy transposon and suppressor genes in Drosophila melanogaster. Genes \& Development 3:454-468.

Fawcett DH, Lister A and Finnegan DH (1986) Transposable elements controlling I-R hybrid dysgenesis in D. melanogaster are similar to mammalian LINEs. Cell 47:1007-1015.

Finnegan DJ (1992) Transposable elements. In: DL Lindsley and G Zimm (eds) The genome of Drosophila melanogaster. Academic Press, New York, pp 1092-1107.

Hammer SE, Strehl S and Hagemann S (2005) Homologs of Drosophila $P$ transposons were mobile in zebrafish but have been domesticated in a common ancestor of chicken and human. Mol Biol Evol 22:833-844.
Handler AM and Gomez SP (1996) The hobo transposable element excises and has related elements in tephritid species. Genetics 143:1339-1347.

Herédia F, Loreto ELS and Valente VLS (2004) Complex Evolution of gypsy in drosophilid species. Mol Biol Evol 21:1-12.

Huisjer P, Kirchhoff C, Lankenau DH and Hennig W (1988) Retrotransposon-like sequences are expressed in Y chromosomal lampbrush loops of Drosophila hydei. J Mol Biol 203:689-697.

Hunter AS and Hunter RA (1964) The mesophragmatica species group of Drosophila in Colombia. Ann Entomo Soc Amer 57:732-736.

Jowett T (1986) Preparation of nucleic acids. In: DB Roberts (ed) Drosophila: A Practical Approach. IRL Press, Washington, D.C., pp 275-288.

Kaminker JS, Bergman CM, Kronmiller B, Carlson J, Svirskas R, Patel S, Frise E, Wheeler DE, Lewis S, Rubin GS, Ashburner M and Celniker SE (2002) The transposable elements of the Drosophila melanogaster euchromatin: A genomics perspective. Genome Biology 3:1-20.

Kidwell MG (1992) Horizontal transfer of $P$ elements and other short repeat transposons. Genetica 86:275-286.

Kidwell MG and Lisch D (2000) Transposable elements and host genome evolution. Trends Ecol Evol 15:95-99.

Kim A, Terzian C, Santamaria P, Pélisson A, Prud'homme N and Bucheton A (1994) Retroviruses in invertebrates: The gypsy retrotransposon is apparently an infectious retrovirus of Drosophila melanogaster. Proc Natl Acad Sci USA 91:1285-1289.

Klein CC (2002) Estudo de fenômenos possivelmente relacionados com a mobilização de elementos transponíveis e à presença de endoparasitas em populações de Drosophila willistoni. M. Sc. Thesis, Universidade Federal do Rio Grande do Sul, Porto Alegre.

Lee SH, Clark JB and Kidwell MG (1999) A $P$ element homologous sequence in the house fly, Musca domestica. Insect Mol Biol 8:491-500.

Loreto ELS, da Silva LB, Zaha A and Valente VL (1998) Distribution of transposable elements in neotropical species of Drosophila. Genetica 101:153-165.

Maruyama K and Hartl DL (1991) Evolution of the transposable element mariner in Drosophila species. Genetics 128:319329.

Moschetti R, Caggese C, Barsanti P and Caizzi R (1998) Intra and interspecies variation among Bari-1 elements of the melanogaster species group. Genetics 150:239-250.

O'Hare K and Rubin GM (1983) Structures of $P$ transposable elements and their sites of insertion and excision in the Drosophila melanogaster genome. Cell 34:25-35.

Oliveira de Carvalho M, Silva JC and Loreto ELS (2004) Analyses of $P$-like transposable element sequences from the genome of Anopheles gambiae. Insect Mol Biol 13:55-63.

Perkins HD and Howells AJ (1992) Genomic sequences with homology to the $P$ element of Drosophila melanogaster occur in the blowfly Lucilia cuprina. Proc Natl Acad Sci USA 89:10753-10757.

Periquet G, Lemeunier F, Bigot Y, Hamelin MH, Bazin C, Ladevèze V, Eeken J, Galindo MI, Pascual L and Boussy I (1994) The evolutionary genetics of the hobo transposable element in the Drosophila melanogaster complex. Genetica 93:7990. 
Poulter RTM, Goodwin TJD and Butler MI (2003) Vertebrate helentrons and other novel Helitrons. Gene 313:201-212.

Prud'homme N, Gans M, Massom M, Terzian C and Bucheton A (1994) Flamenco, a gene controlling the gypsy retrovirus of Drosophila melanogaster. Genetics 139:697-711.

Quesneville H, Nouaud D and Anxolabehere D (2005) Recurrent recruitment of the THAP DNA-binding domain and molecular domestication of the $P$-transposable element. Mol Biol Evol 22:741-746.

Robertson HM and MacLeod EG (1993) Five major subfamilies of mariner transposable elements in insects, including the Mediterranean fruit fly, and related arthropods. Insect Mol Biol 2:125-139.

Sarkar A, Sengupta R, Krzywinski J, Wang X, Roth C and Collins FH (2003) $P$ elements are found in the genomes of nema- toceran insects of the genus Anopheles. Insect Biochem Mol Biol 33:381-387.

Stacey SN, Lansman RA, Brock HW and Grigliatti TA (1986) Distribution and conservation of mobile elements in the genus Drosophila. Mol Biol Evol 3:522-534.

Tanda S, Shrimpton AE, Chueh LL, Itayama H, Matsubayashi H, Saigo K, Tobari YN and Langley CH (1988) Retrovirus-like features and site specific insertions of a transposable element, Tom, in Drosophila ananassae. Mol Gen Genet 214:405-411.

Torti C, Gomulski LM, Bonizzoni M, Murelli V, Moralli D, Guglielmino CR, Raimondi E, Crisafulli D, Capy P, Gasperi G and Malacrida AR (2005) Cchobo, a hobo-related sequence in Ceratitis capitata. Genetica 123:313-325.

Associate Editor: Louis Bernard Klaczko 